\title{
Immunologic Monitoring of Cellular Responses by Dendritic/Tumor Cell Fusion Vaccines
}

\author{
Shigeo Koido, ${ }^{1,2,3}$ Sadamu Homma, ${ }^{3}$ Akitaka Takahara, ${ }^{1}$ Yoshihisa Namiki, ${ }^{2}$ Hideo Komita, ${ }^{1}$ \\ Eijiro Nagasaki, ${ }^{3}$ Masaki Ito, ${ }^{3}$ Keisuke Nagatsuma, ${ }^{1}$ Kan Uchiyama, ${ }^{1}$ Kenichi Satoh, ${ }^{1}$ \\ Toshifumi Ohkusa, ${ }^{1}$ Jianlin Gong, ${ }^{4}$ and Hisao Tajiri ${ }^{1}$ \\ ${ }^{1}$ Division of Gastroenterology and Hepatology, Department of Internal Medicine, The Jikei University School of Medicine, \\ Tokyo 105-8461, Japan \\ ${ }^{2}$ Institute of Clinical Medicine and Research, The Jikei University School of Medicine, Tokyo 105-8461, Japan \\ ${ }^{3}$ Department of Oncology, Institute of DNA Medicine, The Jikei University School of Medicine, Tokyo 105-8461, Japan \\ ${ }^{4}$ Department of Medicine, Boston University School of Medicine, Boston, MA 02118, USA \\ Correspondence should be addressed to Shigeo Koido, shigeo_koido@jikei.ac.jp
}

Received 12 August 2010; Revised 11 November 2010; Accepted 27 February 2011

Academic Editor: Theresa L. Whiteside

Copyright (c) 2011 Shigeo Koido et al. This is an open access article distributed under the Creative Commons Attribution License, which permits unrestricted use, distribution, and reproduction in any medium, provided the original work is properly cited.

\begin{abstract}
Although dendritic cell (DC)- based cancer vaccines induce effective antitumor activities in murine models, only limited therapeutic results have been obtained in clinical trials. As cancer vaccines induce antitumor activities by eliciting or modifying immune responses in patients with cancer, the Response Evaluation Criteria in Solid Tumors (RECIST) and WHO criteria, designed to detect early effects of cytotoxic chemotherapy in solid tumors, may not provide a complete assessment of cancer vaccines. The problem may, in part, be resolved by carrying out immunologic cellular monitoring, which is one prerequisite for rational development of cancer vaccines. In this review, we will discuss immunologic monitoring of cellular responses for the evaluation of cancer vaccines including fusions of DC and whole tumor cell.
\end{abstract}

\section{Introduction}

The mechanism of action for most cancer vaccines is mainly mediated through cytotoxic T lymphocytes (CTLs). We are now gaining a clear understanding of the cellular events leading to an effective CTL-mediated antitumor immunity. The antigen-presenting cells (APCs) most suitable for cancer vaccines are dendritic cells (DCs), which can be distinguished from B cells and macrophages by their abundant expression of costimulatory molecules and abilities to initiate a strong primary immune response $[1,2]$. DCs are specialized to capture and process tumor-associated antigens (TAAs), converting the proteins to peptides that are presented on major histocompatibility complex (MHC) class I and class II molecules [3]. After TAAs uptake and inflammatory stimulation, immature DCs in peripheral tissues undergo a maturation process characterized by the upregulation of costimulatory molecules $[2,3]$. During this process, mature DCs migrate to T-cell areas of secondary lymphoid organs, where they present antigenic peptides to CD8+ and CD4+ T cells through MHC class I and class II pathways, respectively, and become competent to present antigens to $\mathrm{T}$ cells, thus initiating antigen-specific CTL responses [4]. Antigen-specific CTLs in turn can attack tumor cells that express cognate antigenic determinants or can provide help for B-cell responses that produce antibodies, which can also lead to tumor cell death in some cases [5]. Thus, the mechanism of action for cancer vaccines, based on harnessing host immune cells to infiltrate tumors and to exert CTL responses, is quite different from that of a traditional cytotoxic chemotherapy [6].

\section{DC-Based Cancer Vaccines}

A major area of investigation in induction of antitumor immunity involves the design of DC-based cancer vaccines [7]. DCs derive their potency from constitutive and inducible expression of essential costimulatory molecules including 
B7, ICAM-1, LFA-1, LFA-3, and CD40 on the cell surface $[1,8,9]$. These proteins function in concert to generate a network of secondary signals essential for reinforcing the primary antigen-specific signals in T-cell activation. Therefore, many strategies have been developed to load TAAs onto DCs and used as cancer vaccines. For example, DCs are pulsed with synthetic peptides derived from the known antigens [10], tumor lysates [11], tumor RNA [12, 13], and dying tumor cells [14] to induce antigen-specific antitumor immunity. Although the production of DC-based cancer vaccines for individual patients with cancer has currently been addressed in clinical trials, a major drawback of these strategies comes from the limited number of known antigenic peptides available in many HLA contexts. Moreover, the results of clinical trials using DCs pulsed with antigenspecific peptides show that clinical responses have been found in a small number of patients $[15,16]$. To overcome this limitation, we have proposed the fusions of DCs and whole tumor cell (DC/tumor) to generate cell hybrids with the characteristics of APCs able to process endogenously provided whole TAAs [17]. The whole tumor cells may be postulated to serve as the best source of antigens [17-21].

\section{DC/Tumor Fusion Vaccines}

The fusion of DC and tumor cell through chemical [17], physical [22], or biological means [23] creates a heterokaryon which combines DC-derived costimulatory molecules, efficient antigen-processing and -presentation machinery, and an abundance of tumor-derived antigens including those yet to be unidentified (Figure 1). Thus, the DC/tumor fusion cells combine the essential elements for presenting tumor antigens to host immune cells and for inducing effective antitumor responses. Now, it is becoming clear that the tumor antigens are processed along the endogenous pathway, through the antigen processing machinery of human DC. Thus, it is conceivable that tumor antigens synthesized de novo in the heterokaryon are processed and presented through the endogenous pathway. The advantage of DC/tumor fusion vaccines over pulsing DC with whole tumor lysates is that endogenously synthesized antigens have better access to MHC class I pathway [18-21]. Indeed, it has been demonstrated that DC/tumor fusion vaccines are superior to those involving other methods of DC loaded with antigenic proteins, peptides, tumor cell lysates, or irradiated tumor cells in murine models [18-21]. The efficacy of antitumor immunity induced by DC/tumor fusion vaccines has been demonstrated in murine models using melanoma [2432], colorectal [17, 30, 31, 33-41], breast [42-47], esophageal [48], pancreatic [49, 50], hepatocellular [51-55], lung $[22,41,56-59]$, renal cell [60] carcinoma, sarcoma [6166], myeloma [67-74], mastocytoma [75], lymphoma [76], and neuroblastoma [77]. The fusion cells generated with human DC and tumor cell also have the ability to present multiple tumor antigens, thus increasing the frequency of responding $\mathrm{T}$ cells and maximizing antitumor immunity capable of killing tumor targets such as colon [78-84], gastric $[85,86]$, pancreatic [87], breast [47, 88-93], laryngeal [94], ovarian [95-97], lung [85, 98], prostate $[99,100]$, renal cell
[101, 102], hepatocellular [103-105] carcinoma, leukemia [106-111], myeloma $[112,113]$, sarcoma $[114,115]$, melanoma [116-119], glioma [120], and plasmacytoma [121].

\section{Monitoring of DC/Tumor Fusion Cell Preparations}

Despite the strong preclinical evidences supporting the use of DC/tumor fusions for cancer vaccination, the results of clinical trials so far reported are conflicting [18-21]. One of the reasons is the evidence for fusion cell formation used as clinical trials is not definitive [23]. The levels of fusion efficiency, which can be quantified by determining the percentage of cells that coexpress tumor and DC antigens, are closely correlated with CTL induction in vitro $[82,83]$. Another reason is immunosuppressive substances such as TGF- $\beta$ derived from tumor cells used for fusion cell preparations $[35,47]$. Although tumor-derived TGF- $\beta$ reduces the efficacy of DC/tumor fusion vaccines via an in vivo mechanism [35], the reduction of TGF- $\beta$ derived from the fusions inhibits the generation of Tregs and enhances antitumor immunity [47]. Moreover, the therapeutic effects in patients vaccinated by DC/tumor fusions are correlated with the characteristics of the DCs used as the fusion vaccines $[82,83]$. Indeed, patient-derived fusions show inferior levels of MHC class II and costimulatory molecules and produce decreased levels of IL-12 and increased levels of IL-10, as compared with those obtained from fusions of tumor cell and DC from healthy donors [87, 103]. However, the fusion vaccines induce recovery of DC function in metastatic cancer patients [103]. Therefore, it is important to assess the phenotype and function of DC/tumor fusion cell preparations used in each vaccination.

\section{In Vivo Monitoring}

The delayed-type hypersensitivity (DTH) is an inflammatory reaction mainly mediated by $\mathrm{CD} 4+$ effector memory $\mathrm{T}$ cells that infiltrate the site of injection of an antigen against which the immune system has been primed by cancer vaccines [122]. Actually, soluble proteins, peptides, or antigens pulsed DCs have been injected intradermally, and the diameter of erythema or induration after $48-72 \mathrm{~h}$ is measured. CD4+ effector memory $\mathrm{T}$ cells that recognize the antigens presented on local APCs mediate the immune responses by releasing cytokines, resulting in an increased vascular permeability and the recruitment of monocytes and other inflammatory cells in the site. CD8 $+\mathrm{T}$ cells less frequently also mediate similar responses [123]. It has been reported that antigenspecific $\mathrm{T}$ cells can be readily detected in skin biopsies from DTH sites, much less in abdominal lymph nodes, and not in peripheral blood and tumor site [124]. Moreover, there is a significant correlation between favorable clinical outcome and the presence of vaccine-related antigen-specific $\mathrm{T}$ cells in biopsies from DTH sites [122]. Indeed, the increased DTH reactivity against tumor antigens has been observed in clinical responders by DC/tumor fusion vaccines [125]. In almost patients with cancer, T cells from lymph nodes and the tumor site itself are not readily available for 

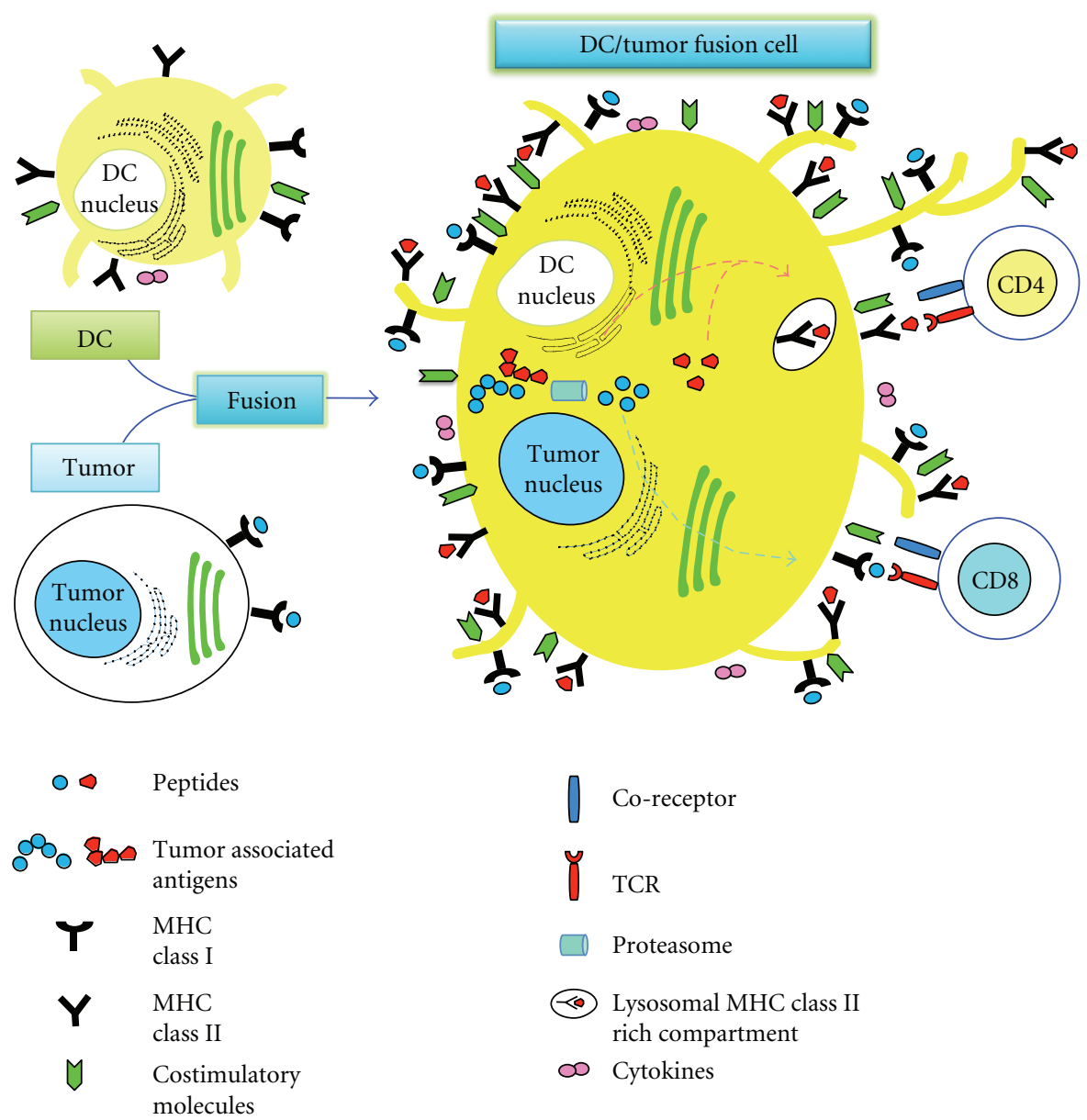

FIGURE 1: A model of antigen processing and presentation by DC/tumor fusion cell. DC/tumor fusion cell expresses MHC class I, class II, costimulatory molecules, and tumor-associated antigens. Tumor-associated antigens can be processed and presented through the antigen processing and presentation pathway of DC.

monitoring purposes. Therefore, functional assessment of antigen-specific T cells from such DTH sites may serve as an additional strategy to evaluate antigen-specific antitumor immune responses [122, 126, 127].

\section{T-Cell Monitoring In Vitro}

The mechanism of cancer vaccines, based on inducing CTLs, infiltrating tumors, and exerting T-cell-mediated cytotoxic effects, is quite different from that of cytotoxic chemotherapy. As cancer vaccines do not work as quickly as chemotherapy which has a direct cytotoxic effect, the Response Evaluation Criteria in Solid Tumors (RECIST) and WHO criteria $[128,129]$, designed to detect early effects of cytotoxic chemotherapy, cannot appropriately evaluate the response patterns observed with cancer vaccines. The RECIST criteria are highly dependent upon measurement of tumor size. They presume that linear measures are an adequate substitute for 2-dimentional methods and register four response categories: CR (complete response), PR (partial response), SD (stable disease), and PD (progressive disease). However, in the solid tumors, there exist not only antigen-specific CTLs but also immune suppressive cells such as myeloid-derived suppressor cells (MDSCs) [130], immunosuppressive tumor-associated macrophages (TAMs) [131], and cancer associated fibroblasts (CAFs) [132] (Figure 2). After vaccination, the solid tumors may become heavily infiltrated by immune-related cells resulting in an apparent increase in size of lesions, which is, at least in part, due to the infiltration of CTLs induced by cancer vaccines. Therefore, the development of new response criteria, including immunologic cellular monitoring, is of great importance in the development of cancer vaccines.

In clinical trials, the peripheral blood T-cell responses are generally accessible for serial analyses. The currently used methods of assessing T-cells from patients treated with cancer vaccines are T-cell proliferation, cytokine profile, cytotoxic T lymphocyte assays (CTL assays), CTL-associated molecules (CD107, perforin, granzyme B, and CD154), multimer analysis, T-cell receptor (TCR) gene usage, and immune suppression assays (Table 1). While these assays can be also used for monitoring cellular immune responses induced by DC/tumor fusion vaccines, none has been standardized. As DC/tumor fusion vaccines can induce defined 


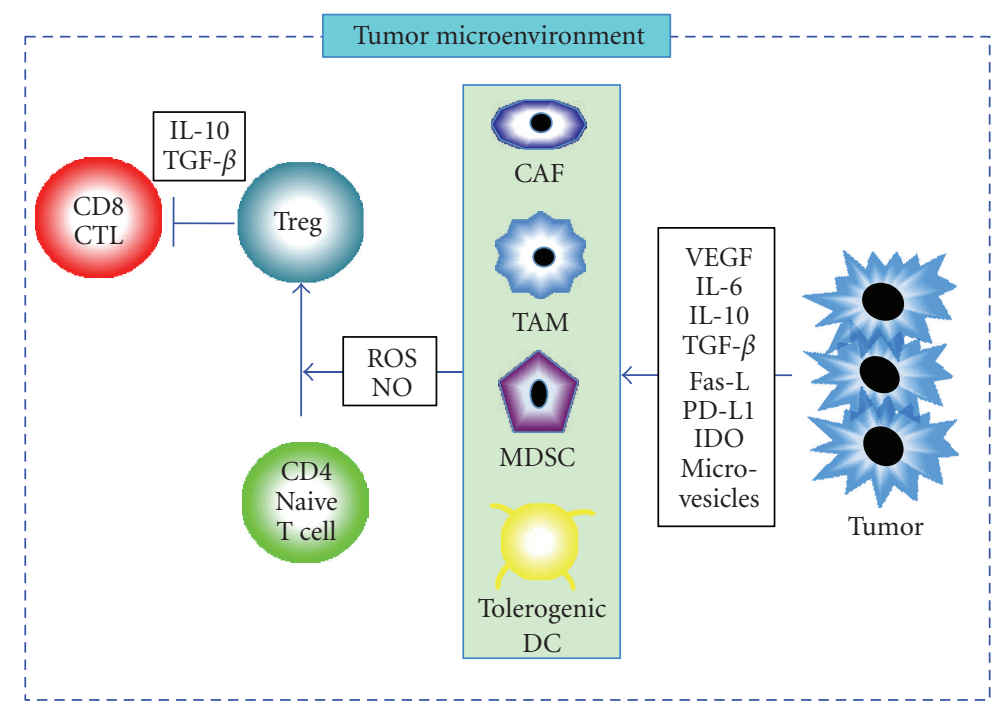

FIGURE 2: Immune suppressive responses at the tumor microenvironment. Tumor cells secrete various factors such as VEGF, IL-6, IL-10, TGF- $\beta$, Fas-L, IDO, PD-L1, and microvesicles, all of which promote the accumulation of heterogeneous populations of tumor-associated macrophage (TAM), myeloid-derived suppressor cell (MDSC), or tolerogenic DC. These immunosuppressive cells inhibit antitumor immunity by various mechanisms, including elaboration of reactive oxygen species (ROS) and nitrogen oxide (NO). The tumor microenvironment also promote the accumulation of regulatory T cell (Treg) that suppresses CD8+ CTL function through secretion of IL-10 or TGF- $\beta$ from Tregs and tumor cells.

and undefined antigen-specific antitumor activities, immunologic cellular monitoring for the fusion vaccines is much more complex. Furthermore, as immune responses induced by DC/tumor fusion vaccines are a balanced mosaic of both immune stimulatory and suppressive responses [92], multiple monitoring assays for the clinical efficacy parameters may be needed to evaluate the antitumor immune responses.

6.1. T-Cell Proliferation. T-cell proliferation assay assesses the number and function at the level of the entire T-cell population in the culture. Therefore, the ability to detect Tcell responses is based on the proliferative potential of the cells in response to antigens. The most commonly used in vitro method for measuring antigen-specific T-cell proliferation is the assessment of T-cell clonal expansion following incubation of T-cells with antigens in the presence of a radiolabeled nucleotide (e.g., $\left[{ }^{3} \mathrm{H}\right]$ thymidine) in vitro. CFSE (5-(and-6)-carboxyfluorescein diacetate succinimidyl ester) staining can be also used to directly detect proliferative responses of T-cells [82]. Because CFSE is partitioned equally during cell division [133], this technique can monitor Tcell division and determine the relationship between $\mathrm{T}$ cell division and differentiation in vitro and in vivo. The extensive T-cell proliferation can be demonstrated by the few undivided T-cells left and from proper accumulation of activated $\mathrm{T}$ cells, as shown by the increase in T-cell counts correlating with the decrease in CFSE label for each division. The CFSE-based assays are equivalent to traditional measures of antigen-specific T-cell responsiveness and have significant advantages for the ability to gate on a specific population of T-cells and the concomitant measurement of T-cell phenotype [134]. After vaccination, $\mathrm{DC} /$ tumor fusion cells can migrate to the T-cell area in the
TABLE 1: Immunologic monitoring.

\begin{tabular}{ll}
\hline $\begin{array}{l}\text { Inflammatory } \\
\text { skin reaction }\end{array}$ & DTH \\
\hline $\begin{array}{l}\text { T-cell } \\
\text { proliferation }\end{array}$ & {$\left[{ }^{3} \mathrm{H}\right]$ thymidine uptake } \\
CFSE dilution
\end{tabular}

regional lymph nodes and form clusters with $\mathrm{CD} 8+$ and CD4+ T cells [34]. Simultaneous recognition of cognate peptides presented by MHC class I and class II molecules on DC/tumor fusion cell is essential in the induction of 
efficient CTLs. Therefore, measuring antigen-specific CD8+ and CD4+ T-cell proliferation is essential to evaluate the induction of vaccine-specific immune responses. Although T-cell proliferation assay is usefulness to detect immune responses in vitro, the results are strongly influenced by the in vitro stimulation procedures. Stimulation of naive $\mathrm{T}$ cells from healthy donors with $\mathrm{DC} /$ tumor fusions in vitro results in potent proliferation of CD4+ and CD8+ T cells $[34,80]$. Therefore, to assess DC/tumor fusion vaccines, antigenspecific CD4+ and CD8+ T cells need to be expanded by stimulation with autologous tumor lysates [103]. In addition, the frozen peripheral blood mononuclear cells (PBMCs) obtained before and after vaccination must be processed in the same set of experiments $[103,135,136]$. As T-cell proliferation assay is biologically irrelevant and imprecise for the reasons stated above, this assay may not be emphasized in future studies.

6.2. Cytokine Production. There is a currently great interest in the assay of polyfunctional $\mathrm{T}$ cells, secreting multiple cytokines (e.g., secreting IFN- $\gamma$ and TNF- $\alpha$ rather than either alone), or expressing multiple surface markers. As the release of Th1 cytokines such as IFN- $\gamma$ and TNF- $\alpha$ is important to determine long-lasting antitumor immunity, a shift to Th1 response by cancer vaccines is essential for therapeutic potential in murine models $[36,37,67$, $77,137,138]$. Therefore, it is important to test whether cancer vaccines can induce a Th1 response in the tumorspecific $\mathrm{T}$ cells, and what impact might this have on the clinical responses. Cytokine production by $\mathrm{T}$ cells in response to antigens can be detected in individual $\mathrm{T}$ cells by enzyme-linked immunospot (ELISPOT) assay [18-21, 139]. Moreover, production of IFN- $\gamma$ captured by antibodies bound to T-cell surface can be detected by flow cytometry analysis $[96,140]$. The actual state of antigen specific Tcell reactivity directly from peripheral blood $\mathrm{T}$ cells can be quantified by IFN- $\gamma$ ELISPOT assay and flow cytometry analysis $[18-21,141]$. As the IFN- $\gamma$ ELISPOT assay shows highly reproducible results among different laboratories, the ELISPOT may be an ideal candidate for robust monitoring of T-cell activity [18-21, 142]. Coculture of CD4+ and CD8+ $\mathrm{T}$ cells from healthy donors with $\mathrm{DC} /$ tumor fusions results in high levels of IFN- $\gamma$ production and low levels of IL-10 production $[50,54,80,143]$. Therefore, to assess DC/tumor fusion vaccines precisely, T cells obtained before and after vaccination might be directly quantified with stimulation of autologous tumor lysates in vitro [103]. In effective clinical responders, comparable levels of IFN- $\gamma$ production in response to tumor lysates may be detected in PBMCs obtained before vaccination. A correlation between IFN- $\gamma$ ELISPOT outcome and effective clinical responses (period free of relapse or survival) has been found in patients treated with cancer vaccines including DC/tumor fusions $[103,135,136,144]$.

6.3. CTL Assays. For immune monitoring of cancer vaccines, T-cell-mediated CTL assays are appealing because measurement of the ability of CTL to kill tumor targets is thought to be a relevant marker for antitumor activity. It has been assumed that the cytotoxicity has been measured in ${ }^{51} \mathrm{Cr}$ release assays in vitro. One drawback to the CTL assays is their relative insensitivity. Instead of ${ }^{51} \mathrm{Cr}$ release assays, flow cytometry-based methods have been developed to assess CTL activity $[145,146]$. Flow cytometry CTL assays can be predicated on measurement of CTL-induced caspase-3 or annexin- $\mathrm{V}$ activation in target cells through fluorescence detection, which are more sensitive to conventional ${ }^{51} \mathrm{Cr}$ release assays [145-147]. These assays show increased sensitivity at early time points after target/effector cell mixing and allow for analysis of target cells in real time at the singlecell level. However, it is unusual to detect antigen-specific killing by $\mathrm{T}$ cells directly isolated from the patients vaccinated with DC/tumor fusions even with the use of flow cytometrybased CTL assays [103, 148]. Therefore, there is a need to stimulate and expand the antigen-specific $\mathrm{T}$ cells in vitro for several days. These stimulations may distort the phenotype and function of the T-cell populations from tumor state. Moreover, it is difficult to obtain sufficient numbers of viable tumor cells from primary lesion due to the length of culture time and potential contamination of bacteria and fungus [79]. Thus, semiallogeneic targets with shared TAAs and MHC class I molecules are necessary instead of autologous targets. Importantly, a majority of the antigen-specific CD8+ CTLs in peripheral blood may not be tumor reactive due to various mechanisms such as downmodulation of MHC class I molecules on tumors and presence of Tregs at the tumor site. Indeed, cytotoxic activity against autologous targets has been observed in peripheral blood $\mathrm{T}$ cells from patients vaccinated with DC/tumor fusions by CTL assays $[103,148]$, but the clinical responses from early clinical trails in patients with melanoma, glioma, gastric, breast, and renal cancer are muted $[103,130,134,135,142,143,148-154]$. The defects of the clinical responses may be caused by the immunosuppressive influences derived from the local tumor microenvironment [103]. In addition, therapeutic antitumor immunity depends on highly migratory CTLs capable of trafficking between lymphoid and tumor sites [155]. Therefore, localization of antigen-specific CTLs demonstrated by analysis of biopsy samples from tumor sites may be directly associated with clinical responses [155].

6.4. Tumor-Specific CD8+ and CD4+ T Cells. The population of CD8+ CTLs can destroy tumor cells through effector molecules (e.g., perforin and granzyme B) [156]. Degranulation of $\mathrm{CD} 107 \mathrm{a}$ and $\mathrm{b}$ is a requisite process of perforin/granzyme B-dependent lytic fashions mediated by responding antigen-specific CTLs. These perforin/granzyme Bdependent lytic fashions require degranulation of CD107a and $b$ in CD8+ CTLs [5]. Therefore, measurement of CD107a and b, perforin, or granzyme B expression by flow cytometric analysis can be combined with intracellular IFN$\gamma$ staining to more completely assess the functionality of CD8+ CTLs $[83,87]$. Moreover, autologous tumor-induced de novo CD154 expression in CD4+ $\mathrm{T}$ cells is highly sensitive for tumor-specific Th cells [157]. The coupling of CD154 expression with multiplexed measurements of 
IFN- $\gamma$ production provides a greater level of detail for the study of tumor-specific CD4+ T-cell responses. Although $\mathrm{DC} /$ tumor fusion vaccines have abilities to induce CD107+ IFN- $\gamma+$ CD8 + T cells and CD154+ IFN- $\gamma+$ CD4+ T cells upon autologous tumor encounter in vitro [83, 87], it has now been unclear the correlation of the assay with clinical outcome.

6.5. Multimer Assays. Now, it has become possible to analyze antigen-specific CD8+ and CD4+ T cells by flow cytometric analysis using multimeric MHC-peptide complexes, measuring the affinity of the TCR to a given epitope [158]. The MHC-peptide multimer analysis is more sensitive to conventional CTL assays [158]. Although DC/tumor fusion vaccines can induce defined and undefined antigensspecific CD8+ and CD4+ T cells, the multimer analysis can only be used to detect immune responses against defined antigenic epitopes expressing in tumor cells [21]. MHCpeptide multimers stably bind to the TCR exhibiting a certain minimal avidity. Hence, there are principal limitations of the multimeric analysis including the suitability and specificity of multimers and the lack of information about the functionality of multimer-positive T cells [158]. The specific role of the multimer-positive $\mathrm{T}$ cells for cancer vaccine efficacy has not yet been well established in the setting of clinical trials. Recent studies suggest that effective cancer vaccines not only stimulate CTL activity, but also sustain long-term memory $\mathrm{T}$ cells capable of mounting strong proliferative and functional responses to secondary tumor antigen challenge [159]. Therefore, it is more important to assess whether multimer-positive $\mathrm{T}$ cells are effector or effector-memory cells. Moreover, the combined use of multimers and functional assays such as IFN- $\gamma$ analysis may have provided some insight into the functional activity of these cells. It has been demonstrated that cryopreserved PBMCs from melanoma patients vaccinated with gp100 peptide show that the majority of multimer-positive CD8+ T cells had either a long-term "effector" (CD45RA+ CCR7-) or an "effector-memory" (CD45RA - CCR7-) phenotype [160]. Interestingly, after vaccination, the resected melanoma patients can mount a significant antigen-specific CD8+ T cell immune response with a production of IFN- $\gamma$ and high proliferation potential [160]. To date, no studies have evaluated the functional activity of multimer-positive $\mathrm{T}$ cells in the blood after vaccination with DC/tumor fusions.

6.6. TCR. Only $\mathrm{T}$ cells having a TCR specific for a given antigen are triggered by interaction with cancer vaccines. This activation results in the clonal expansion of antigenspecific $\mathrm{T}$ cells that can be followed by TCR V $\beta$ gene usage. Recently, the availability of a large panel of monoclonal antibodies against TCRs, mainly $\mathrm{V} \beta$ epitopes, allows one to study the TCR repertoire by flow cytometry [161]. PCR techniques can also be used to detect a restricted TCR repertoire from small amounts of $\mathrm{T}$ cells without biases caused by ex vivo expansions [162]. Although DC/tumor fusion vaccines have resulted in selection and expansion of T-cell clones [87], the generation of antitumor immunity by CTLs has not correlated with clinical responses. Tumors may evade surveillance of CTLs by distinct mechanisms. Immunogenic tolerance to a particular set of antigens is the absence of an immune response to those antigens, which can be achieved by processes that result in T-cell anergy (antigen-specific unresponsiveness), T-cell unresponsiveness (generalized dysfunction), and T-cell deletion (apoptosis) [163]. Future fusion vaccine studies should be designed to determine whether T-cell dysfunction correlated with clinical outcome.

6.7. Immune Suppression Assays. Although antigen-specific CTLs can be generated and detected in the circulation of vaccinated patients, these do not usually act against the tumor. It has been documented that immune suppressive cells can counteract antitumor immune responses. In tumor microenvironment, there are not only CTLs but also many immune suppressive cells such as CD4+ CD25high+ Foxp3+ Tregs [103, 164], MDSCs [130], TAMs [131], and CAFs [132] (Figure 2). Moreover, tumor cells produce immunosuppressive substances such as transforming growth factor $\beta$ (TGF$\beta$ ) [165] vascular endothelial growth factor (VEGF) [166], IL-6 [167], IL-10 [167], soluble Fas ligand (Fas-L) [168], programmed death-1 ligand (PD-L1) [169], indolamine2,3-dioxygenase (IDO) [170], and microvesicles [171]. Type 1 regulatory $\mathrm{T}$ cells $(\mathrm{Tr} 1)$ expressing CD39 may mediate suppression by IL-10, TGF- $\beta$, and adenosine secretion, and whereby accumulation strongly correlates with the cancer progression [172]. The mechanisms that suppress the immune system provide a fundamental reason why cancer vaccines fail to induce consistently robust antitumor immune responses. In DC/tumor fusion vaccines, CD4+ CD25high+ Foxp3+ Tregs were promoted in the presence of the local tumor-related factors in vitro [103]. Moreover, increased CD4+ CD25high+ Foxp3+ Tregs impaired the effector function of CTLs induced by DC/tumor fusion vaccines [103]. Therefore, monitoring of immune suppressive cells in cancer patients vaccinated with DC/tumor fusions is also essential.

\section{Conclusion}

The development of assays for detecting immune responses associated with clinical outcome has been limited. A variety of assays had been introduced to provide monitoring tools necessary for following changes in the frequency of antigenspecific CTLs and to assess the impact of cancer vaccines on the immune system. As the mechanisms of immune response that cause tumor regression are not simple, the currently available assays may not actually measure a function with direct relevance to how tumors are actually attacked immunologically in cancer patients. A high reproducibility of results among different laboratories leads to the conclusion that cytokine flow cytometry or ELISPOT may be an ideal candidate for robust and reproducible monitoring of T-cell activity in vivo. However, the widely used ELISPOT assay often does not correlate the best with clinical outcome [173]. Therefore, it may be important to use a functional assay like 
cytokine flow cytometry or ELISPOT in combination with a quantitative assay like multimers for immune monitoring. Furthermore, it is necessary to understand the immune responses seen in peripheral blood versus the responses at the tumor site. Monitoring of antigen-specific CTLs at the tumor site may be directly associated with clinical responses [155]. However, T cells from lymph nodes and the tumor site itself are not readily available for monitoring purposes in almost all patients. Therefore, the ability to assess the function of antigen-specific T cells from DTH site may serve as an additional strategy to evaluate cancer vaccines $[122,126,127]$. In our opinion, monitoring of multimerpositive CD8+ (effector or effector memory) $\mathrm{T}$ cells from the DTH sites or PBMCs with IFN- $\gamma$ production by flow cytometry may be sensitive markers particularly associated with overall survival. In addition, the DC/tumor fusion vaccine studies should be designed to determine whether $\mathrm{T}$ cell dysfunction in the tumor microenvironment correlated with clinical outcome. This informations may help us more fully understand the mechanisms of cancer vaccines and its potency to hasten the progress of efficient cancer vaccine strategies into the clinic.

\section{Disclosure}

The authors have no relevant affiliations or financial involvement with any organization or entity with a financial interest in or financial conflict with the subject matter or materials discussed in the paper.

\section{Acknowledgments}

This work has been supported by Foundation for Promotion of Cancer Research, Mitsui Life Social Welfare Foundation, Grants-in-Aid for Scientific Research (B) from the Ministry of Education, Cultures, Sports, Science and Technology of Japan, Grant-in-Aid of the Japan Medical Association, Takeda Science Foundation, Pancreas Research Foundation of Japan, and Mitsui Life Social Welfare Foundation.

\section{References}

[1] K. Inaba, M. Pack, M. Inaba, H. Sakuta, F. Isdell, and R. M. Steinman, "High levels of a major histocompatibility complex II-self peptide complex on dendritic cells from the T cell areas of lymph nodes," Journal of Experimental Medicine, vol. 186, no. 5, pp. 665-672, 1997.

[2] J. Banchereau and R. M. Steinman, "Dendritic cells and the control of immunity," Nature, vol. 392, no. 6673, pp. 245252, 1998.

[3] R. M. Steinman and J. Swanson, "The endocytic activity of dendritic cells," Journal of Experimental Medicine, vol. 182, no. 2, pp. 283-288, 1995.

[4] R. M. Steinman, "The dendritic cell system and its role in immunogenicity," Annual Review of Immunology, vol. 9, pp. 271-296, 1991.

[5] M. Barry and R. C. Bleackley, "Cytotoxic T lymphocytes: all roads lead to death," Nature Reviews Immunology, vol. 2, no. 6, pp. 401-409, 2002.
[6] J. D. Wolchok, A. Hoos, S. O’Day et al., "Guidelines for the evaluation of immune therapy activity in solid tumors: immune-related response criteria," Clinical Cancer Research, vol. 15, no. 23, pp. 7412-7420, 2009.

[7] J. Banchereau and A. K. Palucka, "Dendritic cells as therapeutic vaccines against cancer," Nature Reviews Immunology, vol. 5, no. 4, pp. 296-306, 2005.

[8] K. Inaba, M. Witmer-Pack, M. Inaba et al., "The tissue distribution of the B7-2 costimulator in mice: abundant expression on dendritic cells in situ and during maturation in vitro," Journal of Experimental Medicine, vol. 180, no. 5, pp. 1849-1860, 1994.

[9] J. W. Young and K. Inaba, "Dendritic cells as adjuvants for class I major histocompatibility complex-restricted antitumor immunity," Journal of Experimental Medicine, vol. 183, no. 1, pp. 7-11, 1996.

[10] C. M. Celluzzi, J. I. Mayordomo, W. J. Storkus, M. T. Lotze, and L. D. Falo Jr., "Peptide-pulsed dendritic cells induce antigen-specific, CTL-mediated protective tumor immunity," Journal of Experimental Medicine, vol. 183, no. 1, pp. 283-287, 1996.

[11] F. O. Nestle, S. Alijagic, M. Gilliet et al., "Vaccination of melanoma patients with peptide- or tumor lysate-pulsed dendritic cells," Nature Medicine, vol. 4, no. 3, pp. 328-332, 1998.

[12] S. K. Nair, S. Hull, D. Coleman, E. Gilboa, H. K. Lyerly, and M. A. Morse, "Induction of carcinoembryonic antigen (CEA)-specific cytotoxic T-lymphocyte responses in vitro using autologous dendritic cells loaded with CEA peptide or CEA RNA in patients with metastatic malignancies expressing CEA," International Journal of Cancer, vol. 82, no. 1, pp. 121-124, 1999.

[13] S. Koido, M. Kashiwaba, D. Chen, S. Gendler, D. Kufe, and J. Gong, "Induction of antitumor immunity by vaccination of dendritic cells transfected with MUC1 RNA," The Journal of Immunology, vol. 165, no. 10, pp. 5713-5719, 2000.

[14] A. K. Palucka, H. Ueno, J. Connolly et al., "Dendritic cells loaded with killed allogeneic melanoma cells can induce objective clinical responses and MART- 1 specific $\mathrm{CD}^{+} \mathrm{T}$-cell immunity," Journal of Immunotherapy, vol. 29, no. 5, pp. 545$557,2006$.

[15] B. Thurner, I. Haendle, C. Röder et al., "Vaccination with Mage-3A1 peptide-pulsed nature, monocyte-derived dendritic cells expands specific cytotoxic T cells and induces regression of some metastases in advanced stage IV melanoma," Journal of Experimental Medicine, vol. 190, no. 11, pp. 1669-1678, 1999.

[16] A. Mackensen, B. Herbst Jr., JI. L. Chen et al., "Phase I study in melanoma patients of a vaccine with peptide-pulsed dendritic cells generated in vitro from $\mathrm{CD} 34^{+}$hematopoietic progenitor cells," International Journal of Cancer, vol. 89, no. 2, pp. 385-392, 2000.

[17] J. Gong, D. Chen, M. Kashiwaba, and D. Kufe, "Induction of antitumor activity by immunization with fusions of dendritic and carcinoma cells," Nature Medicine, vol. 3, no. 5, pp. 558561, 1997.

[18] S. Koido, E. Hara, S. Homma, K. Fujise, J. Gong, and H. Tajiri, "Dendritic/tumor fusion cell-based vaccination against cancer," Archivum Immunologiae et Therapiae Experimentalis, vol. 55, no. 5, pp. 281-287, 2007.

[19] J. Gong, S. Koido, and S. K. Calderwood, "Cell fusion: from hybridoma to dendritic cell-based vaccine," Expert Review of Vaccines, vol. 7, no. 7, pp. 1055-1068, 2008. 
[20] S. Koido, E. Hara, S. Homma et al., "Cancer vaccine by fusions of dendritic and cancer cells," Clinical and Developmental Immunology, vol. 2009, Article ID 657369, 13 pages, 2009.

[21] S. Koido, S. Homma, E. Hara et al., "Antigen-specific polyclonal cytotoxic T lymphocytes induced by fusions of dendritic cells and tumor cells," Journal of Biomedicine and Biotechnology, vol. 2010, Article ID 752381, 12 pages, 2010.

[22] C. M. Celluzzi and L. D. Falo Jr., "Physical interaction between dendritic cells and tumor cells results in an immunogen that induces protective and therapeutic tumor rejection," The Journal of Immunology, vol. 160, no. 7, pp. 3081-3085, 1998.

[23] S. Shu, R. Zheng, W. T. Lee, and P. A. Cohen, "Immunogenicity of dendritic-tumor fusion hybrids and their utility in cancer immunotherapy," Critical Reviews in Immunology, vol. 27, no. 5, pp. 463-483, 2007.

[24] J. Wang, S. Saffold, X. Cao, J. Krauss, and W. Chen, "Eliciting $\mathrm{T}$ cell immunity against poorly immunogenic tumors by immunization with dendritic cell-tumor fusion vaccines," The Journal of Immunology, vol. 161, no. 10, pp. 5516-5524, 1998.

[25] X. Cao, W. Zhang, J. Wang et al., "Therapy of established tumour with a hybrid cellular vaccine generated by using granulocyte-macrophage colony-stimulating factor genetically modified dendritic cells," Immunology, vol. 97, no. 4, pp. 616-625, 1999.

[26] J. Li, L. M. Holmes, K. J. Franek, K. E. Burgin, T. E. Wagner, and Y. Wei, "Purified hybrid cells from dendritic cell and tumor cell fusions are superior activators of antitumor immunity," Cancer Immunology, Immunotherapy, vol. 50, no. 9, pp. 456-462, 2001.

[27] V. Phan, F. Errington, S. C. Cheong et al., "A new genetic method to generate and isolate small, short-lived but highly potent dendritic cell-tumor cell hybrid vaccines," Nature Medicine, vol. 9, no. 9, pp. 1215-1219, 2003.

[28] K. Shimizu, H. Kuriyama, J. Kjaergaard, W. Lee, H. Tanaka, and S. Shu, "Comparative analysis of antigen loading strategies of dendritic cells for tumor immunotherapy," Journal of Immunotherapy, vol. 27, no. 4, pp. 265-272, 2004.

[29] H. Kuriyama, S. Watanabe, J. Kjaergaard et al., "Mechanism of third signals provided by IL- 12 and OX-40R ligation in eliciting therapeutic immunity following dendritic-tumor fusion vaccination," Cellular Immunology, vol. 243, no. 1, pp. 30-40, 2006.

[30] A. Ishida, H. Tanaka, T. Hiura et al., "Generation of antitumour effector $\mathrm{T}$ cells from naïve $\mathrm{T}$ cells by stimulation with dendritic/tumour fusion cells," Scandinavian Journal of Immunology, vol. 66, no. 5, pp. 546-554, 2007.

[31] E. Ko, W. Luo, L. Peng, X. Wang, and S. Ferrone, "Mouse dendritic-endothelial cell hybrids and 4-1BB costimulation elicit antitumor effects mediated by broad antiangiogenic immunity," Cancer Research, vol. 67, no. 16, pp. 7875-7884, 2007.

[32] S. Šalomskaite-Davalgiene, K. Čepurniene, S. Šatkauskas, M. S. Venslauskas, and L. M. Mir, "Extent of cell electrofusion in vitro and in vivo is cell line dependent," Anticancer Research, vol. 29, no. 8, pp. 3125-3130, 2009.

[33] J. Gong, V. Apostolopoulos, D. Chen et al., "Selection and characterization of MUC1-specific CD8 ${ }^{+} \mathrm{T}$ cells from MUC1 transgenic mice immunized with dendritic-carcinoma fusion cells," Immunology, vol. 101, no. 3, pp. 316-324, 2000.

[34] S. Koido, Y. Tanaka, D. Chen, D. Kufe, and J. Gong, "The kinetics of in vivo priming of CD4 and CD8 T cells by dendritic/tumor fusion cells in MUC1-transgenic mice," The Journal of Immunology, vol. 168, no. 5, pp. 2111-2117, 2002.

[35] J. Y. Kao, Y. Gong, C. M. Chen, Q. D. Zheng, and J. J. Chen, "Tumor-derived TGF- $\beta$ reduces the efficacy of dendritic cell/ tumor fusion vaccine," The Journal of Immunology, vol. 170, no. 7, pp. 3806-3811, 2003.

[36] T. Inuma, S. Homma, T. Noda, D. Kufe, T. Ohno, and G. Toda, "Prevention of gastrointestinal tumors based on adenomatous polyposis coli gene mutation by dendritic cell vaccine," Journal of Clinical Investigation, vol. 113, no. 9, pp. 1307-1317, 2004.

[37] T. Suzuki, T. Fukuhara, M. Tanaka et al., "Vaccination of dendritic cells loaded with interleukin-12-secreting cancer cells augments in vivo antitumor immunity: characteristics of syngeneic and allogeneic antigen-presenting cell cancer hybrid cells," Clinical Cancer Research, vol. 11, no. 1, pp. 5866, 2005.

[38] J. Y. Kao, M. Zhang, C. M. Chen, and J. J. Chen, "Superior efficacy of dendritic cell-tumor fusion vaccine compared with tumor lysate-pulsed dendritic cell vaccine in colon cancer," Immunology Letters, vol. 101, no. 2, pp. 154-159, 2005.

[39] F. Xu, Y. J. Ye, Z. R. Cui, and S. Wang, "Allogeneic dendritomas induce anti-tumour immunity against metastatic colon cancer," Scandinavian Journal of Immunology, vol. 61, no. 4, pp. 364-369, 2005.

[40] T. Yasuda, T. Kamigaki, K. Kawasaki et al., "Superior antitumor protection and therapeutic efficacy of vaccination with allogeneic and semiallogeneic dendritic cell/tumor cell fusion hybrids for murine colon adenocarcinoma," Cancer Immunology, Immunotherapy, vol. 56, no. 7, pp. 1025-1036, 2007.

[41] E. I. Cho, C. Tan, G. K. Koski, P. A. Cohen, S. Shu, and W. T. Lee, "Toll-like receptor agonists as third signals for dendritic cell-tumor fusion vaccines," Head and Neck, vol. 32, no. 6, pp. 700-707, 2010.

[42] J. Gong, D. Chen, M. Kashiwaba et al., "Reversal of tolerance to human MUC1 antigen in MUC1 transgenic mice immunized with fusions of dendritic and carcinoma cells," Proceedings of the National Academy of Sciences of the United States of America, vol. 95, no. 11, pp. 6279-6283, 1998.

[43] M. Lindner and V. Schirrmacher, "Tumour cell-dendritic cell fusion for cancer immunotherapy: comparison of therapeutic efficiency of polyethylen-glycol versus electro-fusion protocols," European Journal of Clinical Investigation, vol. 32, no. 3, pp. 207-217, 2002.

[44] J. Xia, Y. Tanaka, S. Koido et al., "Prevention of spontaneous breast carcinoma by prophylactic vaccination with dendritic/tumor fusion cells," The Journal of Immunology, vol. 170, no. 4, pp. 1980-1986, 2003.

[45] D. Chen, J. Xia, Y. Tanaka et al., "Immunotherapy of spontaneous mammary carcinoma with fusions of dendritic cells and mucin 1-positive carcinoma cells," Immunology, vol. 109, no. 2, pp. 300-307, 2003.

[46] H. Tamai, S. Watanabe, R. Zheng et al., "Effective treatment of spontaneous metastases derived from a poorly immunogenic murine mammary carcinoma by combined dendritictumor hybrid vaccination and adoptive transfer of sensitized T cells," Clinical Immunology, vol. 127, no. 1, pp. 66-77, 2008.

[47] M. Zhang, B. E. Berndt, J. J. Chen, and J. Y. Kao, "Expression of a soluble TGF- $\beta$ receptor by tumor cells enhances dendritic cell/tumor fusion vaccine efficacy," The Journal of Immunology, vol. 181, no. 5, pp. 3690-3697, 2008. 
[48] G. H. Guo, S. Z. Chen, J. Yu et al., "In vivo anti-tumor effect of hybrid vaccine of dendritic cells and esophageal carcinoma cells on esophageal carcinoma cell line 109 in mice with severe combined immune deficiency," World Journal of Gastroenterology, vol. 14, no. 8, pp. 1167-1174, 2008.

[49] C. Ziske, P. E. Etzrodt, A. S. Eliu et al., "Increase of in vivo antitumoral activity by CD40L (CD154) gene transfer into pancreatic tumor cell-dendritic cell hybrids," Pancreas, vol. 38, no. 7, pp. 758-765, 2009.

[50] M. Yamamoto, T. Kamigaki, K. Yamashita et al., "Enhancement of anti-tumor immunity by high levels of Th1 and Th17 with a combination of dendritic cell fusion hybrids and regulatory T cell depletion in pancreatic cancer," Oncology Reports, vol. 22, no. 2, pp. 337-343, 2009.

[51] S. Homma, G. Toda, J. Gong, D. Kufe, and T. Ohno, "Preventive antitumor activity against hepatocellular carcinoma (HCC) induced by immunization with fusions of dendritic cells and HCC cells in mice," Journal of Gastroenterology, vol. 36 , no. 11, pp. 764-771, 2001.

[52] J. K. Zhang, J. Li, J. Zhang, H. B. Chen, and S. B. Chen, "Antitumor immunopreventive and immunotherapeutic effect in mice induced by hybrid vaccine of dendritic cells and hepatocarcinoma in vivo," World Journal of Gastroenterology, vol. 9, no. 3, pp. 479-484, 2003.

[53] M. Iriei, S. Homma, H. Komita et al., "Inhibition of spontaneous development of liver tumors by inoculation with dendritic cells loaded with hepatocellular carcinoma cells in C3H/HeNCRJ mice," International Journal of Cancer, vol. 111, no. 2, pp. 238-245, 2004.

[54] H. M. Zhang, L. W. Zhang, W. C. Liu, J. Cheng, X. M. Si, and J. Ren, "Comparative analysis of DC fused with tumor cells or transfected with tumor total RNA as potential cancer vaccines against hepatocellular carcinoma," Cytotherapy, vol. 8 , no. 6 , pp. 580-588, 2006.

[55] XI. L. Sheng and H. Zhang, "In-vitro activation of cytotoxic $\mathrm{T}$ lymphocytes by fusion of mouse hepatocellular carcinoma cells and lymphotactin gene-modified dendritic cells," World Journal of Gastroenterology, vol. 13, no. 44, pp. 5944-5950, 2007.

[56] J. Šímová, J. Bubeník, J. Bieblová, M. Indrová, and T. Jandlová, "Immunotherapeutic efficacy of vaccines generated by fusion of dendritic cells and HPV16-associated tumour cells," Folia Biologica, vol. 51, no. 1, pp. 19-24, 2005.

[57] R. Savai, R. T. Schermuly, M. Schneider et al., "Hybridprimed lymphocytes and hybrid vaccination prevent tumor growth of Lewis lung carcinoma in mice," Journal of Immunotherapy, vol. 29, no. 2, pp. 175-187, 2006.

[58] R. Savai, R. T. Schermuly, S. S. Pullamsetti et al., "A combination hybrid-based vaccination/adoptive cellular therapy to prevent tumor growth by involvement of T cells," Cancer Research, vol. 67, no. 11, pp. 5443-5453, 2007.

[59] X. Ou, S. Cai, P. Liu et al., "Enhancement of dendritic celltumor fusion vaccine potency by indoleamine-pyrrole 2,3dioxygenase inhibitor, 1-MT," Journal of Cancer Research and Clinical Oncology, vol. 134, no. 5, pp. 525-533, 2008.

[60] W. M. Siders, K. L. Vergilis, C. Johnson, J. Shields, and J. M. Kaplan, "Induction of specific antitumor immunity in the mouse with the electrofusion product of tumor cells and dendritic cells," Molecular Therapy, vol. 7, no. 4, pp. 498-505, 2003.

[61] J. Kjaergaard, K. Shimizu, and S. Shu, "Electrofusion of syngeneic dendritic cells and tumor generates potent therapeutic vaccine," Cellular Immunology, vol. 225, no. 2, pp. 65-74, 2003.
[62] H. Matsue, K. Matsue, D. Edelbaum, M. Walters, A. Morita, and A. Takashima, "New strategy for efficient selection of dendritic cell-tumor hybrids and clonal heterogeneity of resulting hybrids," Cancer Biology and Therapy, vol. 3, no. 11, pp. 1145-1151, 2004.

[63] G. Y. Kim, H. J. Chae, K. H. Kim et al., "Dendritic cell-tumor fusion vaccine prevents tumor growth in vivo," Bioscience, Biotechnology and Biochemistry, vol. 71, no. 1, pp. 215-221, 2007.

[64] Z. Yu, B. Ma, Y. Zhou et al., "Allogeneic tumor vaccine produced by electrofusion between osteosarcoma cell line and dendritic cells in the induction of antitumor immunity," Cancer Investigation, vol. 25, no. 7, pp. 535-541, 2007.

[65] R. Zheng, P. A. Cohen, C. A. Paustian et al., "Paired toll-like receptor agonists enhance vaccine therapy through induction of interleukin-12," Cancer Research, vol. 68, no. 11, pp. 40454049, 2008.

[66] S. Yanai, Y. Adachi, J. I. Fuijisawa et al., "Anti-tumor effects of fusion cells of type 1 dendritic cells and Meth A tumor cells using hemagglutinating virus of Japan-envelope," International Journal of Oncology, vol. 35, no. 2, pp. 249-255, 2009.

[67] J. Gong, S. Koido, D. Chen et al., "Immunization against murine multiple myeloma with fusions of dendritic and plasmacytoma cells is potentiated by interleukin 12," Blood, vol. 99, no. 7, pp. 2512-2517, 2002.

[68] W. Zhang, H. Yang, and H. Zeng, "Enhancing antitumor by immunization with fusion of dendritic cells and engineered tumor cells," Journal of Huazhong University of Science and Technology. Medical Science, vol. 22, no. 1, pp. 1-4, 2002.

[69] Y. Liu, W. Zhang, T. Chan, A. Saxena, and J. Xiang, "Engineered fusion hybrid vaccine of IL-4 gene-modified myeloma and relative mature dendritic cells enhances antitumor immunity," Leukemia Research, vol. 26, no. 8, pp. 757-763, 2002.

[70] S. Hao, X. Bi, S. Xu et al., "Enhanced antitumor immunity derived from a novel vaccine of fusion hybrid between dendritic and engineered myeloma cells," Experimental Oncology, vol. 26, no. 4, pp. 300-306, 2004.

[71] D. Xia, F. Li, and J. Xiang, "Engineered fusion hybrid vaccine of IL-18 gene-modified tumor cells and dendritic cells induces enhanced antitumor immunity," Cancer Biotherapy and Radiopharmaceuticals, vol. 19, no. 3, pp. 322-330, 2004.

[72] M. Shi, L. Su, S. Hao, X. Guo, and J. Xiang, "Fusion hybrid of dendritic cells and engineered tumor cells expressing interleukin-12 induces type 1 immune responses against tumor," Tumori, vol. 91, no. 6, pp. 531-538, 2005.

[73] S. Quéant, C. O. Sarde, M. G. Gobert, J. Kadouche, and A. Roseto, "Antitumor response against myeloma cells by immunization with mouse syngenic dendritoma," Hybridoma, vol. 24, no. 4, pp. 182-188, 2005.

[74] E. Alvarez, E. Moga, J. Barquinero, J. Sierra, and J. Briones, "Dendritic and tumor cell fusions transduced with adenovirus encoding CD40L eradicate B-cell lymphoma and induce a Th17-type response," Gene Therapy, vol. 17, no. 4, pp. 469-477, 2010.

[75] L. Lespagnard, P. Mettens, A. M. Verheyden et al., "Dendritic cells fused with mastocytoma cells elicit therapeutic antitumor immunity," International Journal of Cancer, vol. 76, no. 2, pp. 250-258, 1998.

[76] J. W. Wells, C. J. Cowled, D. Darling et al., "Semi-allogeneic dendritic cells can induce antigen-specific T-cell activation, which is not enhanced by concurrent alloreactivity," Cancer 
Immunology, Immunotherapy, vol. 56, no. 12, pp. 1861-1873, 2007.

[77] H. Iinuma, K. Okinaga, R. Fukushima et al., "Superior protective and therapeutic effects of IL-12 and IL-18 gene-transduced dendritic neuroblastoma fusion cells on liver metastasis of murine neuroblastoma," The Journal of Immunology, vol. 176, no. 6, pp. 3461-3469, 2006.

[78] A. Draube, M. Beyer, S. Schumer et al., "Efficient activation of autologous tumor-specific T cells: a simple coculture technique of autologous dendritic cells compared to established cell fusion strategies in primary human colorectal carcinoma," Journal of Immunotherapy, vol. 30, no. 4, pp. 359-369, 2007.

[79] S. Koido, E. Hara, S. Homma et al., "Dendritic cells fused with allogeneic colorectal cancer cell line present multiple colorectal cancer-specific antigens and induce antitumor immunity against autologous tumor cells," Clinical Cancer Research, vol. 11, no. 21, pp. 7891-7900, 2005.

[80] S. Koido, E. Hara, A. Torii et al., "Induction of antigenspecific CD4- and CD8-mediated T-cell responses by fusions of autologous dendritic cells and metastatic colorectal cancer cells," International Journal of Cancer, vol. 117, no. 4, pp. 587595, 2005.

[81] B. D. Hock, G. Roberts, J. L. McKenzie et al., "Exposure to the electrofusion process can increase the immunogenicity of human cells," Cancer Immunology, Immunotherapy, vol. 54, no. 9, pp. 880-890, 2005.

[82] S. Koido, E. Hara, S. Homma et al., "Streptococcal preparation OK-432 promotes fusion efficiency and enhances induction of antigen-specific CTL by fusions of dendritic cells and colorectal cancer cells," The Journal of Immunology, vol. 178, no. 1, pp. 613-622, 2007.

[83] S. Koido, E. Hara, S. Homma et al., "Synergistic induction of antigen-specific CTL by fusions of TLR-stimulated dendritic cells and heat-stressed tumor cells," The Journal of Immunology, vol. 179, no. 7, pp. 4874-4883, 2007.

[84] J. Y. Yang, D. Y. Cao, L. Y. Ma, and W. C. Liu, "Dendritic cells fused with allogeneic hepatocellular carcinoma cell line compared with fused autologous tumor cells as hepatocellular carcinoma vaccines," Hepatology Research, vol. 40, no. 5, pp. 505-513, 2010.

[85] K. Imura, Y. Ueda, T. Hayashi et al., "Induction of cytotoxic T lymphocytes against human cancer cell lines using dendritic cell-tumor cell hybrids generated by a newly developed electrofusion technique," International Journal of Oncology, vol. 29, no. 3, pp. 531-539, 2006.

[86] S. Matsumoto, H. Saito, S. Tsujitani, and M. Ikeguchi, "Allogeneic gastric cancer cell-dendritic cell hybrids induce tumor antigen (carcinoembryonic antigen) specific $\mathrm{CD}^{+} \mathrm{T}$ cells," Cancer Immunology, Immunotherapy, vol. 55, no. 2, pp. 131-139, 2006.

[87] S. Koido, E. Hara, S. Homma et al., "Dendritic/pancreatic carcinoma fusions for clinical use: comparative functional analysis of healthy-versus patient-derived fusions," Clinical Immunology, vol. 135, no. 3, pp. 384-400, 2010.

[88] J. Gong, D. Avigan, D. Chen et al., "Activation of antitumor cytotoxic $\mathrm{T}$ lymphocytes by fusions of human dendritic cells and breast carcinoma cells," Proceedings of the National Academy of Sciences of the United States of America, vol. 97, no. 6, pp. 2715-2718, 2000.

[89] Y. Zhang, B. Ma, Y. Zhou et al., "Dendritic cells fused with allogeneic breast cancer cell line induce tumor antigenspecific CTL responses against autologous breast cancer cells," Breast Cancer Research and Treatment, vol. 105, no. 3, pp. 277-286, 2007.

[90] K. Serhal, C. Baillou, N. Ghinea et al., "Characteristics of hybrid cells obtained by dendritic cell/tumour cell fusion in a T-47D breast cancer cell line model indicate their potential as anti-tumour vaccines," International Journal of Oncology, vol. 31, no. 6, pp. 1357-1365, 2007.

[91] S. Koido, Y. Tanaka, H. Tajiri, and J. Gong, "Generation and functional assessment of antigen-specific T cells stimulated by fusions of dendritic cells and allogeneic breast cancer cells," Vaccine, vol. 25, no. 14, pp. 2610-2619, 2007.

[92] B. Vasir, Z. Wu, K. Crawford et al., "Fusions of dendritic cells with breast carcinoma stimulate the expansion of regulatory T cells while concomitant exposure to IL-12, CpG oligodeoxynucleotides, and Anti-CD3/CD28 promotes the expansion of activated tumor reactive cells," The Journal of Immunology, vol. 181, no. 1, pp. 808-821, 2008.

[93] J. Rosenblatt, Z. Wu, B. Vasir et al., "Generation of tumorspecific $t$ lymphocytes using dendritic cell/tumor fusions and anti-CD3/CD28," Journal of Immunotherapy, vol. 33, no. 2, pp. 155-166, 2010.

[94] J. B. Weise, S. Maune, T. Görögh et al., "A dendritic cell based hybrid cell vaccine generated by electrofusion for immunotherapy strategies in HNSCC," Auris Nasus Larynx, vol. 31, no. 2, pp. 149-153, 2004.

[95] J. Gong, N. Nikrui, D. Chen et al., "Fusions of human ovarian carcinoma cells with autologous or allogeneic dendritic cells induce antitumor immunity," The Journal of Immunology, vol. 165, no. 3, pp. 1705-1711, 2000.

[96] S. Koido, M. Ohana, C. Liu et al., "Dendritic cells fused with human cancer cells: morphology, antigen expression, and $\mathrm{T}$ cell stimulation," Clinical Immunology, vol. 113, no. 3, pp. 261-269, 2004.

[97] S. Koido, N. Nikrui, M. Ohana et al., "Assessment of fusion cells from patient-derived ovarian carcinoma cells and dendritic cells as a vaccine for clinical use," Gynecologic Oncology, vol. 99, no. 2, pp. 462-471, 2005.

[98] S. C. Cheong, I. Blangenois, J. D. Franssen et al., "Generation of cell hybrids via a fusogenic cell line," Journal of Gene Medicine, vol. 8, no. 7, pp. 919-928, 2006.

[99] A. Lundqvist, A. Palmborg, G. Bidla, M. Whelan, H. Pandha, and P. Pisa, "Allogeneic tumor-dendritic cell fusion vaccines for generation of broad prostate cancer T-cell responses," Medical Oncology, vol. 21, no. 2, pp. 155-165, 2004.

[100] T. B. Kim, H. K. Park, J. H. Chang et al., "The establishment of dendritic cell-tumor fusion vaccines for hormone refractory prostate cancer cell," Korean Journal of Urology, vol. 51, no. 2, pp. 139-144, 2010.

[101] E. Gottfried, R. Krieg, C. Eichelberg, R. Andreesen, A. Mackensen, and S. W. Krause, "Characterization of cells prepared by dendritic cell-tumor cell fusion," Cancer Immunity, vol. 5, pp. 1-11, 2002.

[102] Z. Hu, S. Liu, X. Mai, Z. Hu, and C. Liu, "Anti-tumor effects of fusion vaccine prepared by renal cell carcinoma 786-O cell line and peripheral blood dendritic cells of healthy volunteers in vitro and in human immune reconstituted SCID mice," Cellular Immunology, vol. 262, no. 2, pp. 112-119, 2010.

[103] S. Koido, S. Homma, E. Hara et al., "In vitro generation of cytotoxic and regulatory $\mathrm{T}$ cells by fusions of human dendritic cells and hepatocellular carcinoma cells," Journal of Translational Medicine, vol. 6, article 51, 2008.

[104] D. Y. Cao, J. Y. Yang, S. Q. Yue et al., "Comparative analysis of DC fused with allogeneic hepatocellular carcinoma cell line HepG2 and autologous tumor cells as potential 
cancer vaccines against hepatocellular carcinoma," Cellular Immunology, vol. 259, no. 1, pp. 13-20, 2009.

[105] F. Xu, Y. J. Ye, W. Liu, M. Kong, Y. He, and S. Wang, "Dendritic cell/tumor hybrids enhances therapeutic efficacy against colorectal cancer liver metastasis in SCID mice," Scandinavian Journal of Gastroenterology, vol. 45, no. 6, pp. 707-713, 2010.

[106] J. Galea-Lauri, D. Darling, G. Mufti, P. Harrison, and F. Farzaneh, "Eliciting cytotoxic T lymphocytes against acute myeloid leukemia-derived antigens: evaluation of dendritic cell-leukemia cell hybrids and other antigen-loading strategies for dendritic cell-based vaccination," Cancer Immunology, Immunotherapy, vol. 51, no. 6, pp. 299-310, 2002.

[107] P. Kokhaei, M. R. Rezvany, L. Virving et al., "Dendritic cells loaded with apoptotic tumour cells induce a stronger Tcell response than dendritic cell-tumour hybrids in B-CLL," Leukemia, vol. 17, no. 5, pp. 894-899, 2003.

[108] J. Gong, S. Koido, Y. Kato et al., "Induction of anti-leukemic cytotoxic T lymphocytes by fusion of patient-derived dendritic cells with autologous myeloblasts," Leukemia Research, vol. 28, no. 12, pp. 1303-1312, 2004.

[109] G. A. Banat, N. Usluoglu, M. Hoeck, K. Ihlow, S. Hoppmann, and H. Pralle, "Dendritic cells fused with core binding factor-beta positive acute myeloid leukaemia blast cells induce activation of cytotoxic lymphocytes," British Journal of Haematology, vol. 126, no. 4, pp. 593-601, 2004.

[110] T. Allgeier, S. Garhammer, E. Nößner et al., "Dendritic cell-based immunogens for B-cell chronic lymphocytic leukemia," Cancer Letters, vol. 245, no. 1-2, pp. 275-283, 2007.

[111] Z. Lei, G. M. Zhang, M. Hong, Z. H. Feng, and B. Huang, "Fusion of dendritic cells and $\mathrm{CD} 34^{+} \mathrm{CD} 38^{-}$acute myeloid leukemia (AML) cells potentiates targeting AML-initiating cells by specific CTL induction," Journal of Immunotherapy, vol. 32, no. 4, pp. 408-414, 2009.

[112] N. Raje, T. Hideshima, F. E. Davies et al., "Tumour cell/ dendritic cell fusions as a vaccination strategy for multiple myeloma," British Journal of Haematology, vol. 125, no. 3, pp. 343-352, 2004.

[113] B. Vasir, V. Borges, Z. Wu et al., "Fusion of dendritic cells with multiple myeloma cells results in maturation and enhanced antigen presentation," British Journal of Haematology, vol. 129, no. 5, pp. 687-700, 2005.

[114] Z. Yu, B. Ma, Y. Zhou, M. Zhang, X. Qiu, and Q. Fan, "Activation of antitumor cytotoxic T lymphocytes by fusion of patient-derived dendritic cells with autologous osteosarcoma," Experimental Oncology, vol. 27, no. 4, pp. 273-278, 2005.

[115] W. Guo, Y. Guo, S. Tang, H. Qu, and H. Zhao, "Dendritic cellEwing's sarcoma cell hybrids enhance antitumor immunity," Clinical Orthopaedics and Related Research, vol. 466, no. 9, pp. 2176-2183, 2008.

[116] P. Jantscheff, G. Spagnoli, P. Zajac, and C. Rochlitz, "Cell fusion: an approach to generating constitutively proliferating human tumor antigen-presenting cells," Cancer Immunology, Immunotherapy, vol. 51, no. 7, pp. 367-375, 2002.

[117] M. R. Parkhurst, C. DePan, J. P. Riley, S. A. Rosenberg, and S. Shu, "Hybrids of dendritic cells and tumor cells generated by electrofusion simultaneously present immunodominant epitopes from multiple human tumor-associated antigens in the context of MHC class I and class II molecules," The Journal of Immunology, vol. 170, no. 10, pp. 5317-5325, 2003.

[118] K. T. Trevor, C. Cover, Y. W. Ruiz et al., "Generation of dendritic cell-tumor cell hybrids by electrofusion for clinical vaccine application," Cancer Immunology, Immunotherapy, vol. 53, no. 8, pp. 705-714, 2004.

[119] A. R. Neves, L. F.C. Ensina, L. B. Anselmo et al., "Dendritic cells derived from metastatic cancer patients vaccinated with allogeneic dendritic cell-autologous tumor cell hybrids express more CD86 and induce higher levels of interferongamma in mixed lymphocyte reactions," Cancer Immunology, Immunotherapy, vol. 54, no. 1, pp. 61-66, 2005.

[120] A. E. Sloan and P. Parajuli, "Human autologous dendritic cell-glioma fusions: feasibility and capacity to stimulate $\mathrm{T}$ cells with proliferative and cytolytic activity," Journal of Neuro-Oncology, vol. 64, no. 1-2, pp. 177-183, 2003.

[121] V. L. Sukhorukov, R. Reuss, J. M. Endter et al., "A biophysical approach to the optimisation of dendritic-tumour cell electrofusion," Biochemical and Biophysical Research Communications, vol. 346, no. 3, pp. 829-839, 2006.

[122] E. H. J. G. Aarntzen, C. G. Figdor, G. J. Adema, C. J. A. Punt, and I. J. M. de Vries, "Dendritic cell vaccination and immune monitoring," Cancer Immunology, Immunotherapy, vol. 57, no. 10, pp. 1559-1568, 2008.

[123] P. Puccetti, R. Bianchi, M. C. Fioretti et al., "Use of a skin test assay to determine tumor-specific $\mathrm{CD}^{+}$T cell reactivity," European Journal of Immunology, vol. 24, no. 6, pp. 14461452, 1994.

[124] W. J. Lesterhuis, I. J. M. de Vries, D. H. Schuurhuis et al., "Vaccination of colorectal cancer patients with CEA-loaded dendritic cells: antigen-specific T cell responses in DTH skin tests," Annals of Oncology, vol. 17, no. 6, pp. 974-980, 2006.

[125] A. Märten, S. Renoth, T. Heinicke et al., "Allogeneic dendritic cells fused with tumor cells: preclinical results and outcome of a clinical phase I/II trial in patients with metastatic renal cell carcinoma," Human Gene Therapy, vol. 14, no. 5, pp. 483-494, 2003.

[126] G. A. Waanders, D. Rimoldi, D. Liénard et al., "Melanomareactive human cytotoxic $\mathrm{T}$ lymphocytes derived from skin biopsies of delayed-type hypersensitivity reactions induced by injection of an autologous melanoma cell line," Clinical Cancer Research, vol. 3, no. 5, pp. 685-696, 1997.

[127] I. J. M. de Vries, M. R. Bernsen, W. J. Lesterhuis et al., "Immunomonitoring tumor-specific T cells in delayed-type hypersensitivity skin biopsies after dendritic cell vaccination correlates with clinical outcome," Journal of Clinical Oncology, vol. 23, no. 24, pp. 5779-5787, 2005.

[128] P. Therasse, S. G. Arbuck, E. A. Eisenhauer et al., "New guidelines to evaluate the response to treatment in solid tumors. European Organization for Research and Treatment of Cancer, National Cancer Institute of the United States, National Cancer Institute of Canada," Journal of the National Cancer Institute, vol. 92, no. 3, pp. 205-216, 2000.

[129] A. B. Miller, B. Hoogstraten, M. Staquet, and A. Winkler, "Reporting results of cancer treatment," Cancer, vol. 47, no. 1, pp. 207-214, 1981.

[130] M. A. Morse, J. R. Hall, and J. M. D. Plate, "Countering tumor-induced immunosuppression during immunotherapy for pancreatic cancer," Expert Opinion on Biological Therapy, vol. 9, no. 3, pp. 331-339, 2009.

[131] T. G. Kormelink, A. Abudukelimu, and F. A. Redegeld, "Mast cells as target in cancer therapy," Current Pharmaceutical Design, vol. 15, no. 16, pp. 1868-1878, 2009.

[132] M. Fassnacht, J. Lee, C. Milazzo et al., "Induction of $\mathrm{CD}^{+}$and $\mathrm{CD}^{+}$T-cell responses to the human stromal antigen, fibroblast activation protein: implication for cancer immunotherapy," Clinical Cancer Research, vol. 11, no. 15, pp. 5566-5571, 2005. 
[133] J. Hasbold, A. V. Gett, J. S. Rush et al., "Quantitative analysis of lymphocyte differentiation and proliferation in vitro using carboxyfluorescein diacetate succinimidyl ester," Immunology and Cell Biology, vol. 77, no. 6, pp. 516-522, 1999.

[134] Y. Tanaka, S. Koido, J. Xia et al., "Development of antigenspecific $\mathrm{CD}^{+} \mathrm{CTL}$ in MHC class I-deficient mice through CD4 to CD8 conversion," The Journal of Immunology, vol. 172, no. 12, pp. 7848-7858, 2004.

[135] D. Avigan, B. Vasir, J. Gong et al., "Fusion cell vaccination of patients with metastatic breast and renal cancer induces immunological and clinical responses," Clinical Cancer Research, vol. 10, no. 14, pp. 4699-4708, 2004.

[136] D. E. Avigan, B. Vasir, D. J. George et al., "Phase I/II study of vaccination with electrofused allogeneic dendritic cells/autologous tumor-derived cells in patients with stage IV renal cell carcinoma," Journal of Immunotherapy, vol. 30, no. 7, pp. 749-761, 2007.

[137] T. Kikuchi, Y. Akasaki, T. Abe et al., "Vaccination of glioma patients with fusions of dendritic and glioma cells and recombinant human interleukin 12," Journal of Immunother$a p y$, vol. 27, no. 6, pp. 452-459, 2004.

[138] S. Homma, T. Kikuchi, N. Ishiji et al., "Cancer immunotherapy by fusions of dendritic and tumour cells and rh-IL-12," European Journal of Clinical Investigation, vol. 35, no. 4, pp. 279-286, 2005.

[139] C. Czerkinsky, G. Andersson, H. P. Ekre, L. A. Nilsson, L. Klareskog, and O. Ouchterlony, "Reverse ELISPOT assay for clonal analysis of cytokine production. I. Enumeration of gamma-interferon-secretion cells," Journal of Immunological Methods, vol. 110, no. 1, pp. 29-36, 1988.

[140] M. A. Suni, L. J. Picker, and V. C. Maino, "Detection of antigen-specific T cell cytokine expression in whole blood by flow cytometry," Journal of Immunological Methods, vol. 212, no. 1, pp. 89-98, 1998.

[141] A. Schmittel, U. Keilholz, and C. Scheibenbogen, "Evaluation of the interferon- $\gamma$ ELISPOT-assay for quantification of peptide specific T lymphocytes from peripheral blood," Journal of Immunological Methods, vol. 210, no. 2, pp. 167174, 1997.

[142] A. Schmittel, U. Keilholz, E. Thiel, and C. Scheibenbogen, "Quantification of tumor-specific T lymphocytes with the ELISPOT assay," Journal of Immunotherapy, vol. 23, no. 3, pp. 289-295, 2000.

[143] J. Rosenblatt, B. Vasir, L. Uhl et al., "Vaccination with dendritic cell/tumor fusion cells results in cellular and humoral antitumor immune responses in patients with multiple myeloma," Blood, vol. 117, no. 2, pp. 393-402, 2011.

[144] C. Scheibenbogen, A. Schmittel, U. Keilholz et al., "Phase 2 trial of vaccination with tyrosinase peptides and granulocytemacrophage colony-stimulating factor in patients with metastatic melanoma," Journal of Immunotherapy, vol. 23, no. 2, pp. 275-281, 2000.

[145] L. Liu, A. Chahroudi, G. Silvestri et al., "Visualization and quantification of $\mathrm{T}$ cell-mediated cytotoxicity using cellpermeable fluorogenic caspase substrates," Nature Medicine, vol. 8, no. 2, pp. 185-189, 2002.

[146] K. R. Jerome, D. D. Sloan, and M. Aubert, "Measuring T-cellmediated cytotoxicity using antibody to activated caspase 3 ," Nature Medicine, vol. 9, no. 1, pp. 4-5, 2003.

[147] J. E. Goldberg, S. W. Sherwood, and C. Clayberger, "A novel method for measuring CTL and NK cell-mediated cytotoxicity using annexin $\mathrm{V}$ and two-color flow cytometry," Journal of Immunological Methods, vol. 224, no. 1-2, pp. 1-9, 1999.
[148] S. Homma, K. Matai, M. Irie, T. Ohno, D. Kufe, and G. Toda, "Immunotherapy using fusions of autologous dendritic cells and tumor cells showed effective clinical response in a patient with advanced gastric carcinoma," Journal of Gastroenterology, vol. 38, no. 10, pp. 989-994, 2003.

[149] T. Kikuchi, Y. Akasaki, M. Irie, S. Homma, T. Abe, and T. Ohno, "Results of a phase I clinical trial of vaccination of glioma patients with fusions of dendritic and glioma cells," Cancer Immunology, Immunotherapy, vol. 50, no. 7, pp. 337344, 2001.

[150] U. Trefzer, G. Weingart, Y. Chen et al., "Hybrid cell vaccination for cancer immune therapy: first clinical trial with metastatic melanoma," International Journal of Cancer, vol. 85, no. 5, pp. 618-626, 2000.

[151] U. Trefzer, G. Herberth, K. Wohlan et al., "Tumour-dendritic hybrid cell vaccination for the treatment of patients with malignant melanoma: immunological effects and clinical results," Vaccine, vol. 23, no. 17-18, pp. 2367-2373, 2005.

[152] S. W. Krause, C. Neumann, A. Soruri, S. Mayer, J. H. Peters, and R. Andreesen, "The treatment of patients with disseminated malignant melanoma by vaccination with autologous cell hybrids of tumor cells and dendritic cells," Journal of Immunotherapy, vol. 25, no. 5, pp. 421-428, 2002.

[153] H. A. Haenssle, S. W. Krause, S. Emmert et al., "Hybrid cell vaccination in metastatic melanoma: clinical and immunologic results of a phase I/II study," Journal of Immunotherapy, vol. 27, no. 2, pp. 147-155, 2004.

[154] J. Zhou, D. Weng, F. Zhou et al., "Patient-derived renal cell carcinoma cells fused with allogeneic dendritic cells elicit anti-tumor activity: in vitro results and clinical responses," Cancer Immunology, Immunotherapy, vol. 58, no. 10, pp. 1587-1597, 2009.

[155] H. Su, D. S. Chang, S. S. Gambhir, and J. Braun, "Monitoring the antitumor response of naive and memory CD8 T cells in $\mathrm{RAG}^{-/-}$mice by positron-emission tomography," The Journal of Immunology, vol. 176, no. 7, pp. 4459-4467, 2006.

[156] O. J. Finn, "Molecular origins of cancer: cancer immunology," The New England Journal of Medicine, vol. 358, no. 25, pp. 2704-2715, 2008.

[157] P. K. Chattopadhyay, J. Yu, and M. Roederer, "A live-cell assay to detect antigen-specific $\mathrm{CD} 4^{+} \mathrm{T}$ cells with diverse cytokine profiles," Nature Medicine, vol. 11, no. 10, pp. 1113-1117, 2005.

[158] J. D. Altman, P. A. H. Moss, P. J. R. Goulder et al., "Phenotypic analysis of antigen-specific T lymphocytes," Science, vol. 274, no. 5284, pp. 94-96, 1996.

[159] C. A. Klebanoff, L. Gattinoni, and N. P. Restifo, "CD8 ${ }^{+}$Tcell memory in tumor immunology and immunotherapy," Immunological Reviews, vol. 211, pp. 214-224, 2006.

[160] E. B. Walker, D. Haley, W. Miller et al., "gp100(209-2M) peptide immunization of human lymphocyte antigen-A2 ${ }^{+}$ stage I-III melanoma patients induces significant increase in antigen-specific effector and long-term memory $\mathrm{CD}^{+} \mathrm{T}$ cells," Clinical Cancer Research, vol. 10, no. 2, pp. 668-680, 2004.

[161] I. Houtenbos, T. M. Westers, A. Dijkhuis, T. D. de Gruijl, G. J. Ossenkoppele, and A. A. van de Loosdrecht, "Leukemiaspecific T-cell reactivity induced by leukemic dendritic cells is augmented by 4-1BB targeting," Clinical Cancer Research, vol. 13, no. 1, pp. 307-315, 2007.

[162] S. A. Kalams, R. P. Johnson, A. K. Trocha et al., "Longitudinal analysis of $\mathrm{T}$ cell receptor (TCR) gene usage by human 
immunodeficiency virus 1 envelope-specific cytotoxic T lymphocyte clones reveals a limited TCR repertoire," Journal of Experimental Medicine, vol. 179, no. 4, pp. 1261-1271, 1994.

[163] F. Ramsdell and B. J. Fowlkes, "Clonal deletion versus clonal anergy: the role of the thymus in inducing self tolerance," Science, vol. 248, no. 4961, pp. 1342-1348, 1990.

[164] J. P. Law, D. F. Hirschkorn, R. E. Owen, H. H. Biswas, P. J. Norris, and M. C. Lanteri, "The importance of Foxp3 antibody and fixation/permeabilization buffer combinations in identifying $\mathrm{CD}^{+} \mathrm{CD} 25^{+} \mathrm{Foxp}^{+}$regulatory T cells," Cytometry Part A, vol. 75, no. 12, pp. 1040-1050, 2009.

[165] B. A. Teicher, "Transforming growth factor- $\beta$ and the immune response to malignant disease," Clinical Cancer Research, vol. 13, no. 21, pp. 6247-6251, 2007.

[166] I. Fricke, N. Mirza, J. Dupont et al., "Vascular endothelial growth factor-trap overcomes defects in dendritic cell differentiation but does not improve antigen-specific immune responses," Clinical Cancer Research, vol. 13, no. 16, pp. 4840-4848, 2007.

[167] K. D. Elgert, D. G. Alleva, and D. W. Mullins, "Tumorinduced immune dysfunction: the macrophage connection," Journal of Leukocyte Biology, vol. 64, no. 3, pp. 275-290, 1998.

[168] A. Houston, M. W. Bennett, G. C. O’Sullivan, F. Shanahan, and J. O'Connell, "Fas ligand mediates immune privilege and not inflammation in human colon cancer, irrespective of TGF- $\beta$ expression," British Journal of Cancer, vol. 89, no. 7, pp. 1345-1351, 2003.

[169] K. Takeda, Y. Kojima, T. Uno et al., "Combination therapy of established tumors by antibodies targeting immune activating and suppressing molecules," The Journal of Immunology, vol. 184, no. 10, pp. 5493-5501, 2010.

[170] C. Uyttenhove, L. Pilotte, I. Théate et al., "Evidence for a tumoral immune resistance mechanism based on tryptophan degradation by indoleamine 2,3-dioxygenase," Nature Medicine, vol. 9, no. 10, pp. 1269-1274, 2003.

[171] M. Szajnik, M. Czystowska, M. J. Szczepanski, M. Mandapathil, and T. L. Whiteside, "Tumor-derived microvesicles induce, expand and up-regulate biological activities of human regulatory T cells (Treg)," PLoS One, vol. 5, no. 7, Article ID e11469, 2010.

[172] L. Strauss, C. Bergmann, M. Szczepanski, W. Gooding, J. T. Johnson, and T. L. Whiteside, "A unique subset of $\mathrm{CD} 4{ }^{+} \mathrm{CD} 25^{\text {high }}$ Foxp $3^{+} \mathrm{T}$ cells secreting interleukin-10 and transforming growth factor- $\beta 1$ mediates suppression in the tumor microenvironment," Clinical Cancer Research, vol. 13, no. 15 , pp. 4345-4354, 2007.

[173] M. Plebanski, M. Katsara, K. C. Sheng, S. D. Xiang, and V. Apostolopoulos, "Methods to measure T-cell responses," Expert Review of Vaccines, vol. 9, no. 6, pp. 595-600, 2010. 


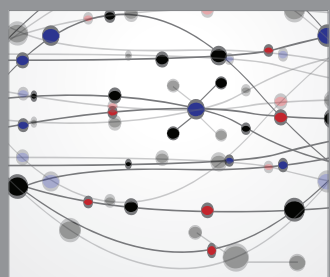

The Scientific World Journal
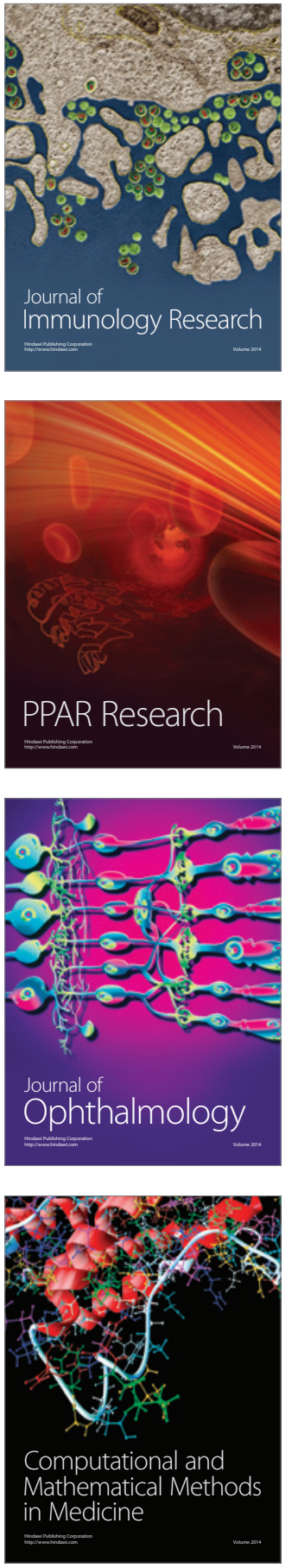

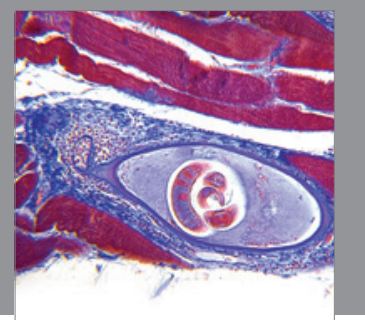

Gastroenterology

Research and Practice
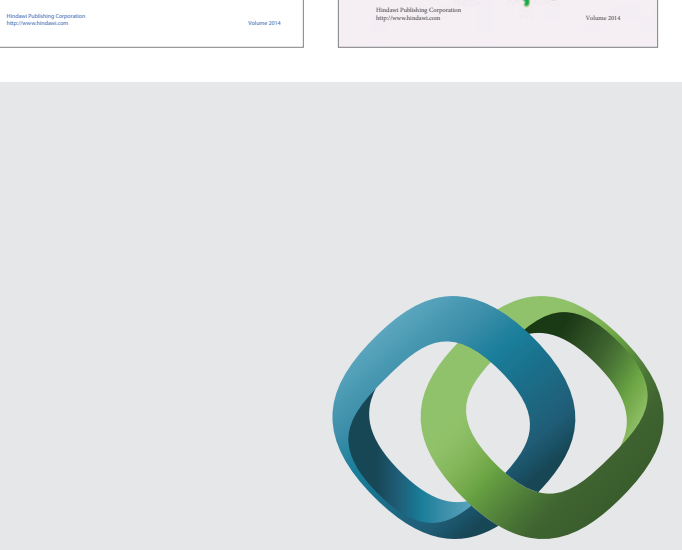

\section{Hindawi}

Submit your manuscripts at

http://www.hindawi.com
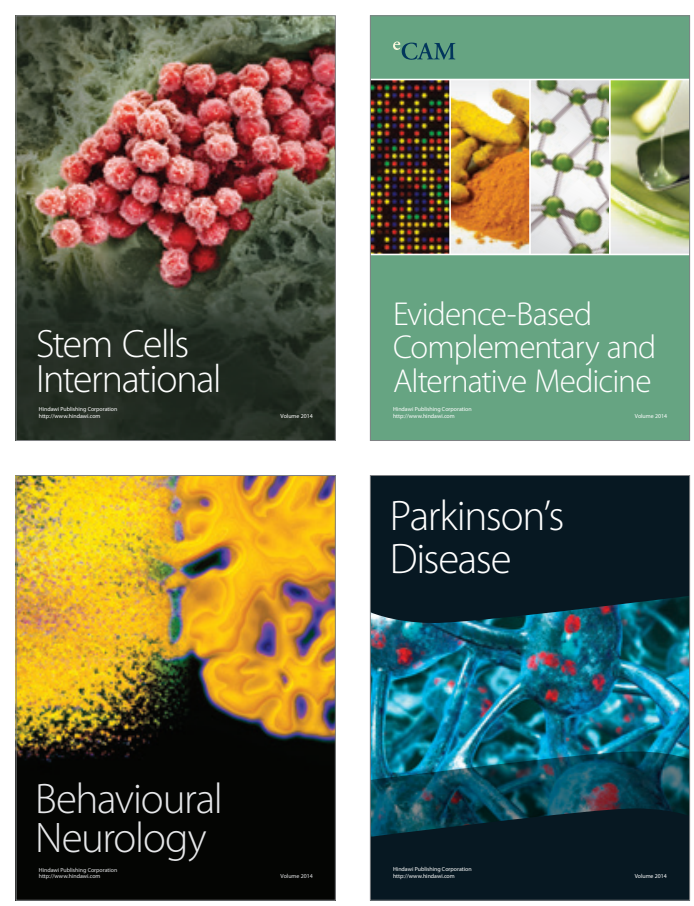

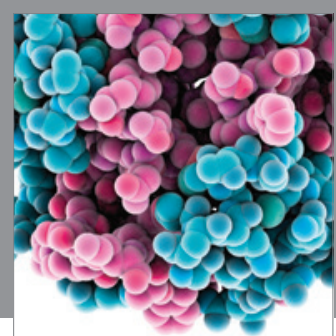

Journal of
Diabetes Research

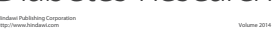

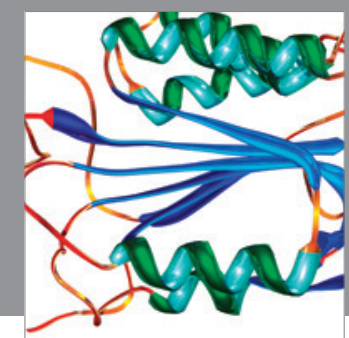

Disease Markers
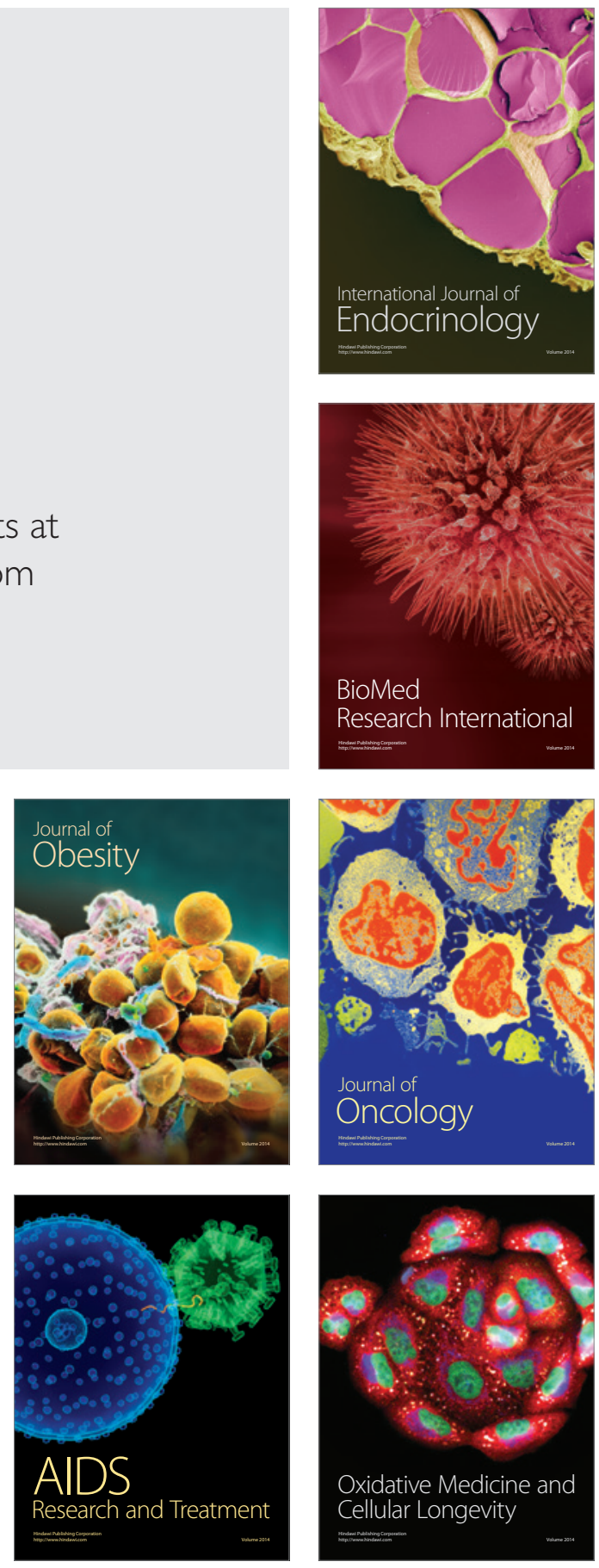